\title{
Study on the Relationship among Private Firms' Political Connection, Diversification and Performance
}

\author{
Jianfeng Lu \\ College of Finance and Trade, Bohai University, Jinzhou, 121013, China \\ lujianfeng9999@126.com
}

Keywords: private company; institution-based view; diversification

\begin{abstract}
Chinese economic in the process of transformation from planned economy to market economy, the reform of the "distributed" and "progressive" caused the regional market segmentation and industry control, due to institutional changes in the economic transformation will experience a process from friction to fusion, corporate diversification strategy of costs and benefits over the same period is closely related to the institutional environment, so the performance of different strategic choices will also vary. This paper analyzes the private enterprise of political association have any impact on regional diversity and diversified industry respectively. Discusses the influence of private enterprises political association on regional diversity and industry diversified respectively. Discusses where is the border of private enterprise's political association impact on diversification strategy. Perfect the enterprise diversification strategy based on system theory framework.
\end{abstract}

\section{Private Enterprises and Political Impact on Industry Diversification Strategy}

Under the condition of China's transition, the main industry diversification objective of private enterprise is in the pursuit of new enterprise value increase opportunities. However, if private enterprises realize enterprise growth strategy is subject to the enterprise external environment, also subject to the enterprise internal resources, the political association has important influence on the private enterprises overcome external environment and internal resources constraints in the process of enterprise industry diversification From the external environment, private enterprises also have been suffering the industry access policy "discrimination". Due to the government's strict control of industry admittance, many industry high barriers to entry, and basically all monopoly by the state-owned enterprises, this entry caused great obstacles for the private enterprise, thus private enterprises through the establishment of good political relations to help its breakthrough control barriers. In the existing literature, hilleman, Zardkoohi and Bierman (1999) argue that corporate political behavior is helpful to obtain the government's market access; Weiwu (2004) study also suggests the market access of the government is a political competition advantage of the enterprise. From the internal environment, the development of the private enterprises still largely depend on the political association the non-market system access to resources. Because of private enterprises through political association for non-market mechanism to master or allocated resources tend to be capital and talent resources, commonality and common resources can support the operation of a variety of patterns, therefore, the rational private enterprises can maximize the use of common resources, to reinvestment of different industry or market, thus, the phenomenon of the highly diversified enterprise appeared. In other words, from the government to get the corresponding resources, preferential tax policy, industry access and government procurement contract is the important reason for promoting industry diversified enterprises.

\section{The Political Association of Private Enterprises, System of Regional Differences and Diversity Strategy}

By comparing the political association of private enterprises in a relatively perfect market system and the relative backward area, get the result is: the private enterprise from the relatively perfect market system, its political association didn't stronger positive impact on regional diversity; on the other hand, the private enterprises in relatively backward area, the political association has a 
stronger positive effect on industry diversification. Serious unbalanced regional development problems in China, it is not a single refers to the gap of economic level, more important is the deep-seated reasons for the unbalanced development. the core of Economic development is to establish a set of fair trade and encourage enterprises to maintain market create wealth market support system, but the local government understanding of this point and practice is not consistent, so lead to market-based degree of regional differences. The reason is that China's system transformation is a multilateral game gradual process (Ruilong Yang and Jijing Yang, 2000). On the one hand, there is a certain order for the reform and opening, the earliest open is eastern and southern coastal provinces, these areas take the lead in implementing the economic reform, in many aspects for the construction of the market-oriented system walk in front of the national reform. On the other hand, the central government in order to stimulate the local government to carry out "distributed" reform, gives local economic governance control power, under the drive of local interests, cause market segmentation. Therefore, although China is a political system highly unified national, different initial conditions and development led to the foundation and institutional evolvement path around the distinction, in different areas of the transition phase system has bigger difference (Du Lu and Tao, 2008). Under the situation of market segmentation, marketing support improvement of the system has important influence on corporate behavior (danglu Luo, 2009). When a region due to the system construction is relatively backward lead to low Market level, the influence of political association will be stronger, and in a high degree area of Market level, political association instead of formal institution and fill the void system function will be weakened.

To sum up, the private enterprises continue to invest in government relations and social networks, actually recognition of the current institutional environment from government-led industry opportunities. But the pattern of China distributed and gradual reform lead to institutional development imbalances, now that private enterprises take advantage of political association is determined by the local government's economic role, then the market degree of different area can also lead to political associated effect size exists difference. Therefore, this article through the analysis of the regulation system of different regional, clearly descript of the development trend of the informal institutional factors, namely in the formal market system constantly improve, under the condition of enterprise political association which can play a more and more small role of alternative, thus further verified the system theory can explain enterprise diversification theory.

\section{The Private Enterprises Political Association, Administrative Level Characteristics and Diversification Strategy}

Local governments by intervene in the diversified behavior of private enterprises, enlarge the markets in the region's business scope and number of jobs. The economic conflict is that if local governments carry out policies which damage the interests of other area or the nation's market, the central government should stand up, calls for strengthening the regional cooperation and orderly competition, even come on policies and regulations to help companies cross-regional development. the current system of market's basic feature is "political focus, economic decentralization", the supervision of local government system is not perfect, with the central government level political association of private enterprises, enterprises will have a broader region within the scope of the social network, in this network of non-market capital will become rare resources and capabilities, with the help of local government across its cultivation and special relationship, help them to win in a wider relationship. Although China's local governments at all levels, regard promote local economic development as the most important goal, but they must obey the instructions and the authority of the central government, so private enterprises can take advantage of this kind of system arrangement of power between the central and local governments, to provide convenient for their own development. And as the central government's official overseas to serve the local government, private enterprises hire retired central government officials as an adviser. Those with the central political association private enterprises can use the agent in the central government, to build a bridge of communication with local governments negotiated by the central vertical management department. This will help to private enterprises in a wider scope to establish good business 
relationship, and served for the political umbrella of the enterprise, to reduce the "hand of plunder" comes from the local government, improve the ability of geographic diversification development of private enterprises.

\section{Diversification Strategy and Performance of Private Enterprise}

China's transformation is a long-term system, will experience a system of "friction" to "system integration" transition. China is still in the mid-term of Friction system, some characteristics of China's situation in the short term, such as market segmentation and relationship oriented institutional factors is difficult to change. So for most private enterprises of insufficient funds, lack of resources or not enough experience, with geographical diversification gradually increase, the costs of external market expansion and internal organization will also increase quickly. Specifically, in wider operating range, private enterprises face the more and more unfamiliar trading object, the institutional environment difference large lead to the transaction cost, make its undergo the opportunism and moral hazard are more and more big. At the beginning of the geographic diversification, development of private enterprises may to neighboring provinces and cities, the environment and cultural distance difference are not very big, but once the enterprise across to further region, the internal management communication difficulty of enterprise will increase significantly. If private enterprises don't have a certain ability of organization, geographical diversity degree of increase will have a negative impact to the enterprise, and reduce short-term performance.

But if the system transformation in various parts of the country into the fusion stage, the private enterprise through economies of scale over the geographic diversification can completely eliminate the early high transaction costs due to market segmentation, and cross-regional business will also have the learning curve effect, enterprises can overcome geographic diversification of the early does not adapt, gradually learn how to use the specific advantage for trans-regional economic shift production and marketing. That on the one hand can gain a broader range of cheap cost, on the other hand, can also according to the product life cycle, will introduce the product of the economic developed areas to economic less developed areas, it will be take big benefits for the private enterprises which implementation regional diversity, thus gain a broader market and more opportunities to improve the enterprise growing value in the future. Private enterprise business concentrated in a few areas, the large amount of investment for a particular strategy belongs to the prediction of single wire, such will be subject to big risk. When the environment changes, the private enterprise to quickly adjust positioning will be a very difficult thing, because of the enterprise will suffer to the time compression. Enterprise expected change and understand the potential market, make more investment, equivalent to create a combination of a strategy for the future, so as to quickly respond to market integration in the future. Although the combination of options may restraint of cross-regional development ability is insufficient, caused by rising costs. But by learning to accumulate knowledge of potential new markets, and then invest, can be seen as the process of establishing the option combination step by step.

In the region of formal system is relatively backward, and market level is low, informal institution suggests that regional diversity and industry diversification is negatively related to the enterprise short-term performance. However, based on the enterprise growing value of real options to provide us with a set of new tools, data prove that private enterprise geographic diversification significantly improved the long-term growth of private enterprises, and industry diversification have no effect on enterprise growth. These findings real described private enterprises performance of diversification strategy under the trend of institutional transition.

\section{Conclusion}

The Chinese government carryout a new round of economic system reform around overcome market segmentation, if the central government has introduced a unified national market policy, and gradually cut down the economic responsibility and power of local government, then the impact of 
China's enterprise market segmentation will diminish. In this situation, high degree of geographical diversity of private enterprises will have a bigger development space, because they can implement the strategy of horizontal integration in the main business, using the country specific advantages to establish advantage on innovation, so as to rapidly improve its international competitiveness.

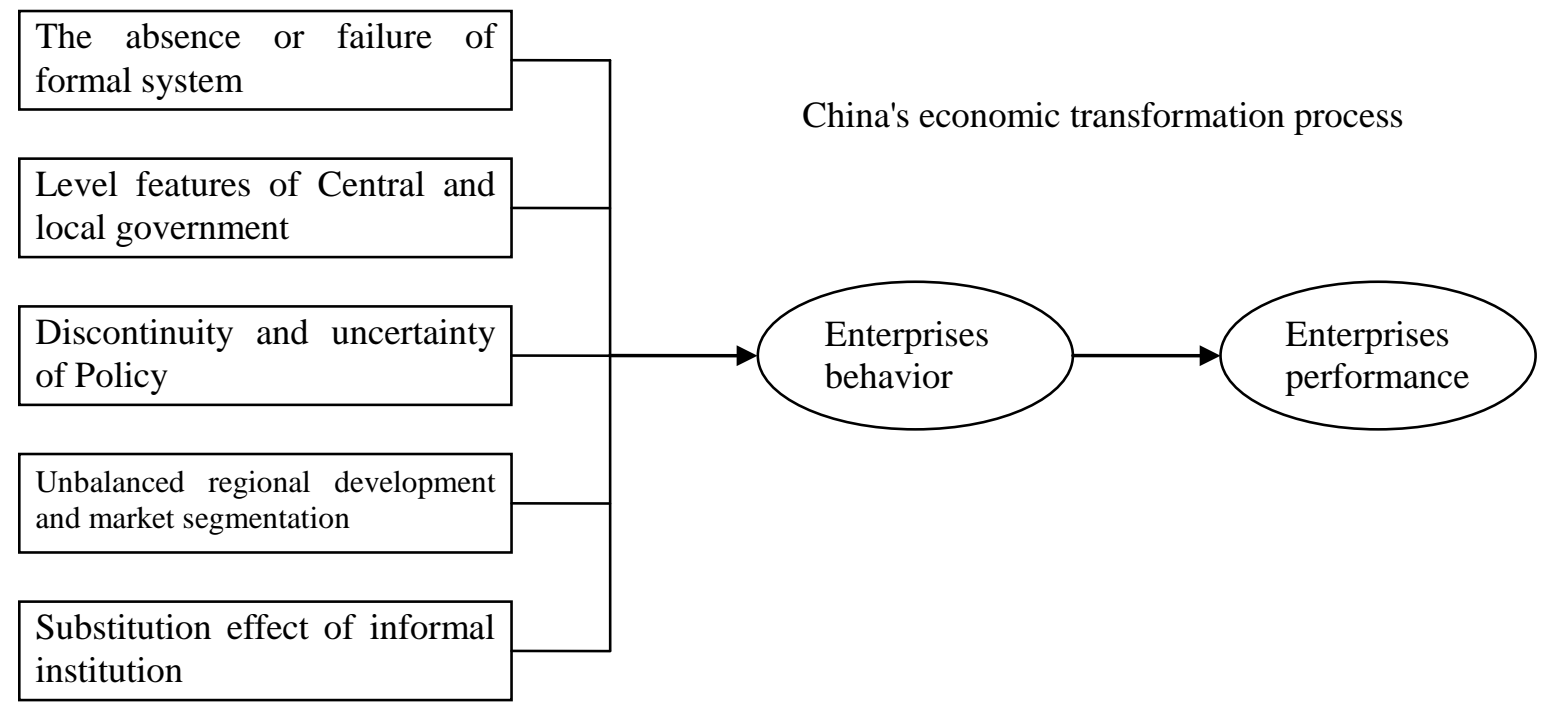

Fig. 1. System- behavior- Performance logic

For private enterprises, the limitation of the external market economic transition cause by government intervention or the traditional social network instead of market mechanism to allocate resources. In addition, the spirit of contract and legal mechanisms does not exist, the private enterprise can not protect their private property rights rely on the legal system, so they resort to informal way to replace the missing market support system. Therefore, political relation not only become an alternative mechanism of legal protection of private enterprises, but also a resources channel, it can help the private enterprises obtain the necessary protection and resource diversification, and influence the degree of diversified private enterprises. on the other hand, as analysis before, the enterprise diversification strategy performance is also influenced by the process of economic transformation, this kind of performance not only refers to short-term financial performance, more important is the growth of enterprise long-term competitive advantage.

\section{References}

[1] Feng T., Wang G. How Private Enterprises Establish Organizational Legitimacy in China's Transitional Economy[J]. Journal of Management Development. 2010, 29(4):377-393.

[2] Estrin S., Prevezer M. The Role of Informal Institutions in Corporate Governance :Brazil, Russia, India, and China Compared[J]. Asia Pacific Journal of Management.2011, 28(1): 41-67.

[3] Sheng S., Zhou K. Z., Li J. J. The Effects of Business and Political Ties on FirmPerformance: Evidence from China[J]. Journal of Marketing. 2011, 75(1): 1-15.

[4] Kim H., Kim H., Hoskisson R. E. Does Market-Oriented Institutional Change in an Emerging Economy Make Business-Group-Affiliated Multinationals Perform Better?An Institution-Based View[J]. Journal of International Business Studies. 2010, 41(7):1141-1160.

[5] Lu Y. Political Connections and Trade Expansion[J].Economics of Transition.2011,19(2): 231.

[6] Wan W. P., Hoskisson R. E., Short J. C. et al. Resource-Based Theory and Corporate Diversification[J]. Journal of management. 2011, 37(5): 1335-1368.

[7] Park S. H., Luo Y. Guanxi and Organizational Dynamics: Organizational Networking in Chinese Firms[J]. Strategic Management Journal. 2001, 22(5): 455-477. 